Received 22.06.2016 Reviewed 25.10 .2016 Accepted 15.11.2016

A - study design

B - data collection

C - statistical analysis

D - data interpretation

E - manuscript preparation

F - literature search

\title{
Variability of the water availability in a river lake system - A case study of Lake Symsar
}

\author{
Angela B. KURIATA-POTASZNIK ${ }^{\text {ABCDEF }}$, Sławomir SZYMCZYK ${ }^{\text {DF }}$
}

University of Warmia and Mazury in Olsztyn, Department of Water Resources, Climatology and Environmental Management, ul. Michała Oczapowskiego 2, 10-719 Olsztyn, Poland; e-mail: angela.potasznik@gmail.com, szymek@uwm.edu.pl

For citation: Kuriata-Potasznik A.B., Szymczyk S. 2016. Variability of the water availability in a river lake system A case study of Lake Symsar. Journal of Water and Land Development. No. 31 p. 87-96. DOI: 10.1515/jwld2016-0039.

\begin{abstract}
It is predicted that climate change will result in the diminution of water resources available both on global and regional scales. Local climate change is harder to observe and therefore, while counteracting its effects, it seems advisable to undertake studies on pertinent regional and local conditions. In this research, our aim was to assess the impact of a river and its catchment on fluctuations in the water availability in a natural lake which belongs to a post-glacial river and lake system. River and lake systems behave most often like a single interacting hydrological unit, and the intensity of water exchange in these systems is quite high, which may cause temporary water losses. This study showed that water in the analyzed river and lake system was exchanged approx. every 66 days, which resulted from the total (horizontal and vertical) water exchange. Also, the management of a catchment area seems to play a crucial role in the local water availability, as demonstrated by this research, where water retention was favoured by wooded and marshy areas. More intensive water retention was observed in a catchment dominated by forests, pastures and wetlands. Wasteland and large differences in the land elevation in the tested catchment are unfavourable to water retention because they intensify soil evaporation and accelerate the water run-off outside of the catchment. Among the actions which should be undertaken in order to counteract water deficiencies in catchment areas, rational use and management of the land resources in the catchment are most often mentioned.
\end{abstract}

Key words: evapotranspiration, hydrological condition, meteorological condition, precipitation, river-lake system

\section{INTRODUCTION}

While foreseeing future global warming and increased human interference with the environment, global natural water resources are considered to be threatened. It is estimated that climate change will lead to the diminution of available water resources (specifically the increase in air temperature by $2^{\circ} \mathrm{C}$, according a model of basic data from 1980-2000) [SCHEWE et al. 2014]. Until now, water has been considered a resource which is renewed as a result of its circulation in nature, affected mostly by meteorological conditions, i.e. precipitation, temperature and other vectors of climate change [SCHEWE et al. 2014]. However, based on the studies carried out thus far, a decrease in water availability is anticipated [HADDELAND et al. 2014], both in the regional context - for instance a decrease in the water availability in northwestern England in the next 25 years [FARMANI et al. 2012] - and on the global scale. Consequences include above all constantly decreasing amounts of freshwater. Water deficiency lowers the levels of food safety and economic welfare in many countries 
[SCHEWE et al. 2014]. Climate elements in Olsztyn Lake District, a physicogeographical mesoregion located in Masurian Lake District, have been observed to change since 1848 . For example, an increase in air temperature by about $0.6^{\circ} \mathrm{C}$ each 100 years has been documented as well as a deficit in the climatic water balance noted after 1990 [OKOŃSKI et al. 2009]. Hazard is posed not only by the steadily decreasing amount of water, but also by its constantly deteriorating quality. For example, Lake Symsar presents a serious water quality problem caused by the influx of domestic sewage [POTASZNIK et al. 2014].

Climate change is harder to observe in the local context and therefore, while counteracting its effects, it seems justified to undertake actions aimed at analyzing and investigating regional and local conditions and limitations [FARMANI et al. 2012]. Most of all, regions with arid climates, high temperatures and evaporation exceeding precipitation are exposed to the problem of water shortages. However, because of some unreasonable human actions, where preservation of the balance between the water supply and demand is neglected [FARMANI et al. 2012], this problem is also slowly emerging in other regions, with climates hitherto considered favourable. The Masurian Lake District is a region which enjoys quite favourable meteorological conditions, compared to the other parts of Poland. The lake district lies in an area where maritime and continental climates clash. The amount of precipitation is $600 \mathrm{~mm}$, and the average temperature is approx. $6.5^{\circ} \mathrm{C}$. Numerous lakes and forests affect the local microclimate significantly [KONDRACKI 2000; STACHY et al. 1987; WACNIK et al. 2014].

According to HADDELAND et al. [2014], the construction of water storage reservoirs has had an enormous influence on the global water balance. The presence of surface water bodies in a region favours the formation of a corresponding microclimate, and consequently limits water loss by evaporation. Microclimate is a characterized as a set of meteorological factors specific in a given site [SUN, CHEN 2012]. In a water balance analysis, the difference between the water income and the water outflow is examined, or else the difference between the amount of precipitation, surface and underground water inflow versus the amount of transpiration, evaporation, and surface and underground water outflow is considered [BAJKIEWICZ-GRABOWSKA, MIKULSKI 1996]. Most often, water bodies and reservoirs located in terrain hollows, extremely shallow and having small catchment areas, are particularly exposed to water loss as a result of climate change [SOJA et al. 2013]. On the other hand, in water bodies of the postglacial origin (type of lake: tunnel-valley lakes), characteristic for the discussed lake district, water escapes mostly through surface outflow. Generally, post-glacial lakes often form river-lake systems, or combinations of lakes and rivers flowing through them, often behaving as a single interacting hydrological unit [WASSENAAR et al. 2011].
The intensity of water exchange in these systems is quite high, which may contribute to temporary water losses. The soil/water balance in the catchment area, dependent on land cover, the needs of plants and meteorological conditions (precipitation and temperature), also has a significant impact on the resources of available water. Evaporation from exposed ground is more intensive than in wooded areas, because forests reduce wind velocity [DUPONT et al. 2015], whereas the wind reduces the air humidity deficit. Therefore, planning alternative strategies for land use in area management seems to be crucial in counteracting the problem of water deficiencies [FARMANI et al. 2012].

The aim of the study was to analyze the varibility of water aviability in a catchment of a lake representing a river-lake system, in response to changing meteorological conditions. In this article, an attempt will be made to review meteorological conditions in the 2012-2014 hydrological years, and to identify hydrological conditions in direct catchments of this lake and in the catchments of its inflows. Also, we will make an analysis of the impact of meteorological conditions on water availability in the catchments and finally we will determine the influence of meteorological conditions of water exchange in the lake, including precipitation, evapotranspiration, surface inflow and outflow.

\section{METHODOLOGY}

\section{RESEARCH SITE}

Lake Symsar is located in Olsztyn Lake District, whose geomorphological conditions were shaped during the last glaciation, hence the presence of numerous end moraines, with prevalent glacial clays of various types of texture, and with the dominance of sand and gravel fractions. The textural composition defined as the particle size distribution of particulate material, may have impact on the macronutrient content of soil [CHODAK et al. 2005]. Height differences in the area reach 20 metres. Lake Symsar is a flow-through lake, the last one in the course of the Symsarna River, which flows into the lake's south-eastern side and flows out of it in the northern direction, towards Lidzbark Warmiński. The river flows out from Lake Luterskie (average depth $h: 7.2 \mathrm{~m}$ ), and intersects the lakes: Ławki ( $h: 4.1 \mathrm{~m})$, Blanki ( $h: 4.9 \mathrm{~m})$ and Symsar (h: $4.9 \mathrm{~m}$ - Fig. 1).

Lake Symsar is a remnant of a tunnel valley and is characterized by an elongated shape and diversified bottom. Its maximum depth is $9.1 \mathrm{~m}$. The lake holds $6639500 \mathrm{~m}^{3}$ of water.

The total catchment area (i.e. together with the Symsarna River's catchment area) is 100 times larger than Lake Symsar, and equals $1.35 \mathrm{~km}^{2}$ surface area. On the other hand, the direct catchment area covers $2.2 \mathrm{~km}^{2}$, with two dominant types of land use around the lake, i.e. forests (45\%) and arable land (49\%) (Tab. 1). 


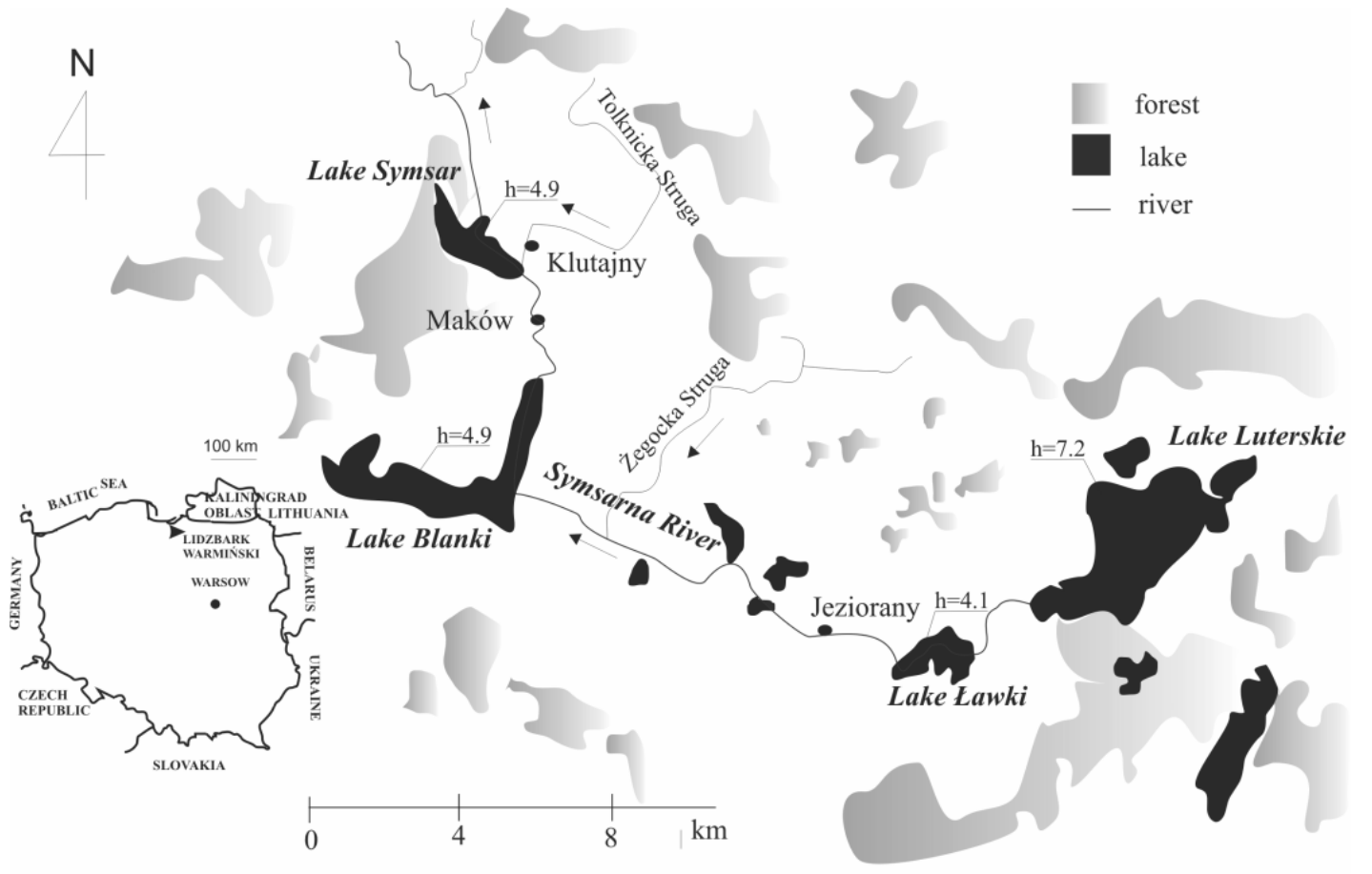

Fig. 1. The course of the Symsarna River; $h=$ average depth of lake; source: own elaboration

Table 1. The land use of the catchment area of Lake Symsar

\begin{tabular}{|l|c|}
\hline \multicolumn{1}{|c|}{ Land cover } & Area, ha \\
\hline \multicolumn{2}{|c|}{ Direct catchment of Lake Symsar } \\
\hline Forests Catchment of Tolknicka Struga \\
\hline Grass/pastures/arable lands & 100.0 \\
\hline Wetlands & 109.0 \\
\hline Lack on plant cover (e.g. roads) & 10.0 \\
\hline \multicolumn{2}{|c|}{ Catchment of stream I } \\
\hline Forests & 1.544 .0 \\
\hline Grass/pastures/arable lands & 162.0 \\
\hline Wetlands & 38.5 \\
\hline \multicolumn{2}{|c|}{ Catchment of stream II } \\
\hline Forests & 99.5 \\
\hline Grass/pastures/arable lands & 92.0 \\
\hline Wetlands & 49.0 \\
\hline \multicolumn{2}{|c|}{ Lake Symsar } \\
\hline Forests & 121.3 \\
\hline Grass/pastures/arable lands & 14.2 \\
\hline \multicolumn{2}{|c|}{} \\
\hline Water table \\
\hline Rushes
\end{tabular}

Source: own elaboration based on Geoportal [2016] data.

The research includes an analysis of water exchange in Lake Symsar and water availability in catchments around the lake (direct lake's catchment and catchments of its inflows: the Tolknicka Struga, stream I and II - Fig. 2).

There are some smaller watercourses flowing into Lake Symsar, apart from the Symsarna River. From the east, it is the Tolknicka Struga (TS). Additionally, wastewater from the Klutajny housing estate, pre- treated in a mechanical (until July 2014) and now mechanical-biological plant with the use of microorganisms and an oxygenation system, flows into the lake (Fig. 2). The catchment area of the Tolknicka Struga (TS), with the surface cover of $19.3 \mathrm{~km}^{2}$, is dominated by arable land $(80 \%$, some used periodically as pastures), while forests constitute $12.5 \%$ of the total area, and the rest is occupied by waterlogged areas (Fig. 2).

From the west, two smaller watercourses flow into the lake; stream I (SI) having a catchment area of $2.8 \mathrm{~km}^{2}$ and flowing into the lake near some summer cabins. In the land use structure of this watercourse's catchment area, forests constitute $57.9 \%$, waterlogged areas make up $28.4 \%$, and the remainder is used for agriculture.

Also, stream II (SII), with a catchment area of $1.41 \mathrm{~km}^{2}$, discharges into the lake. In its final section, the stream flows through wooded areas, occupying approx. $65.3 \%$ of its catchment area. The upper part of this watercourse's catchment area, including its sources, is used for agriculture (arable land and grasslands).

In conclusion, there are four lakes located in the total catchment of Lake Symsar (L), connected to the Symsarna River, thus forming a typical river-lakes system. The last lake in the system is Lake Symsar: a eutrophic water body, where rush vegetation occupies approx. $11.0 \%$ of the water's surface area.

Helophytes prevail in the species composition, with $60 \%$ of common reed communities. The Ecological State Macrophyte Index (ESMI) development factor was 0.336 in 2011 [WIOŚ Olsztyn, IOŚ 2012]. 


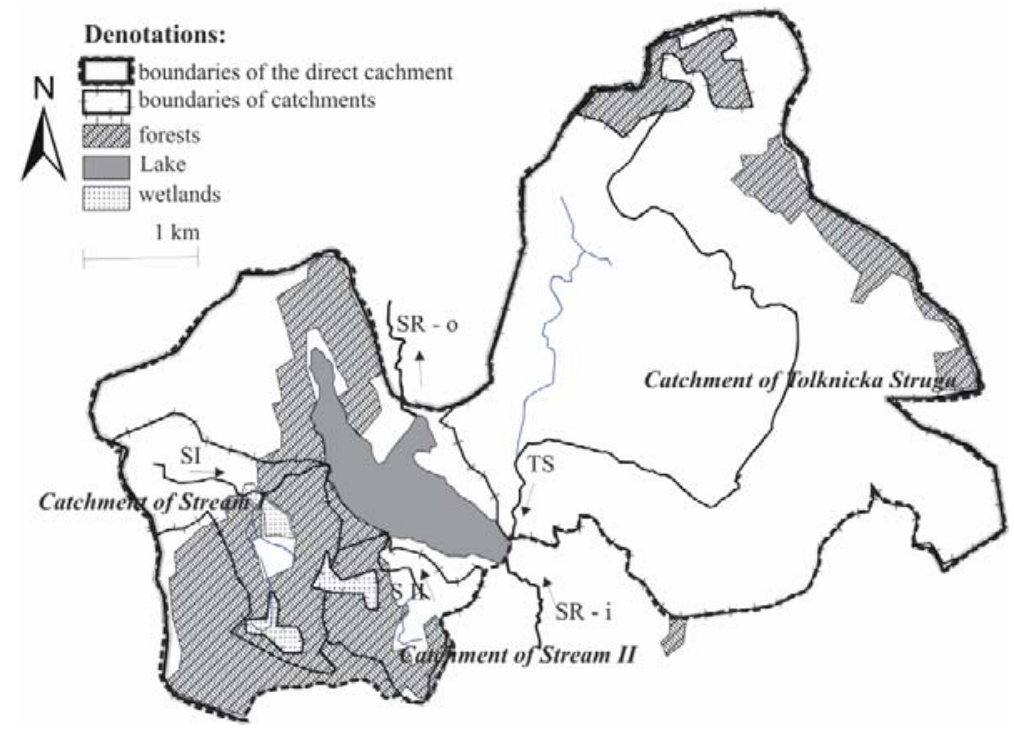

Fig. 2. The land use in the direct catchment area and in the catchment areas of Lake Symsar's inflows; source: own elaboration

\section{METHODOLOGY}

The studies on the water balance of Lake Symsar and the field balances of its partial catchment areas, schematically shown in Figure 3, were carried out from November 2011 to October 2014 (thus including three hydrological years: 2012, 2013 and 2014).

The meteorological data of the period from November 2011 to October 2014 were obtained from the meteorological station in Lidzbark Warmiński, located approx. $8 \mathrm{~km}$ north of the analyzed lake (the sum of atmospheric precipitation, temperature, wind velocity and direction, air humidity), and from the Olsztyn/ Kętrzyn station (insolation), located approx. $50 \mathrm{~km}$ south-west of Olsztyn and east of Kętrzyn, both belonging to the Institute of Meteorology and Water Management National Research Institute in Białystok.

The plant growing season spanned a period with average daily air temperatures equal or above $5^{\circ} \mathrm{C}$ [SIŁUCH, BARTOSZEK 2012]. For the purpose of this study, the following dates were adopted as the onset and end of a plant growing season: 18.04-25.10.2012,
13.04-13.11.2013 and 6.04-21.10.2014. The water availability in partial catchments is presented in Figure 3, where incoming water includes: precipitation and expenditure, including evapotranspiration as the sum of evaporation and transpiration.

The difference between those components indicates excess or deficiency of water. Precipitation is known (based on data from the Institute of Meteorology and Water Management National Research Institute in Białystok), but evaporation (ETo) was derived from the $P-M$ equation proposed by ALLEN et al. [1998], indicative of daily evaporation from the ground surface.

The formula for indicative evaporation proposed by ALLEN et al. [1998] allows for calculating the evaporation from low vegetation well-supplied with water. In order to calculate the actual evaporation inclusive of various types of land use, a combined method was employed, represented by the PenmanMonteith formula [ALLEN 2000; ALLEN et al. 1998; LECHNIO 2005]:

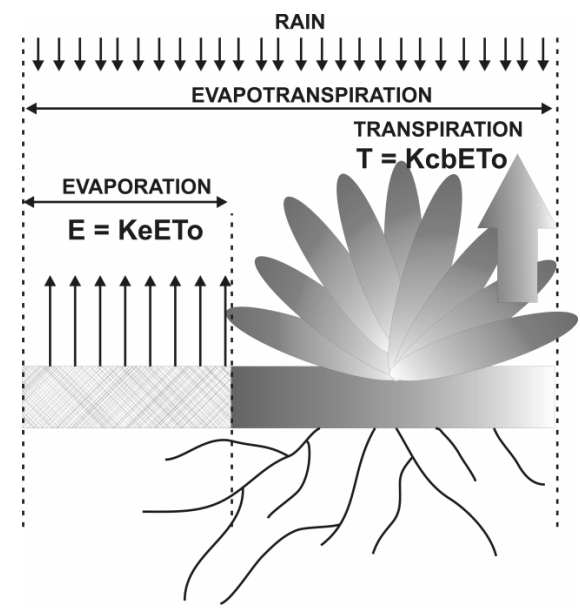

Fig. 3. Diagram of the water balance of the partial catchment areas of Lake Symsar (after ALLEN et al. [1998]); $T=$ the evaporation from the surface of plants, or the phenomenon of transpiration, $E$ = evaporation from the soil is described by the following equation (when the soil is hydrated, the coefficient has higher values; $K c b=K c b^{\prime}$ (from Allen et. al.(1998) $+\left[0.04\left(u_{2}-2\right)-\right.$ $\left.0.004\left(R H_{\min }-45\right)\right](h / 3)^{0.3} ; R H_{\min }=$ the mean value for daily minimum relative humidity: $R H_{\min }=e^{o}\left(T_{\min }\right) / e^{o}\left(T_{\max }\right) ; h=$ the mean plant height during the mid or late season $(\mathrm{m}) ; e^{o}=$ saturation $e^{o}(T)$ vapour pressure at the same temperature; $K e=K r\left(K c_{\max }-K c b\right) ; K r=$ reduction coefficient of the soil evaporation (when the soil is hydrated it has a value of 1 ; during a drought it drops to 0$) ; K c_{\max }=\left\{1.2+\left[0.04\left(u_{2}-2\right)-0.004\left(R H_{\min }-45\right)\right]\right.$ $\left.(h / 3)^{0.3}\right\}$ or just $K c_{\max }=K c b+0.05$ it is a value following rain or irrigation; source: own elaboration 


$$
E T=E t o K c
$$

where: $E T=$ terrain evaporation (actual) $(\mathrm{mm})$, ETo $=$ indicative evaporation for the land covered with low grass, on well-hydrated soil $(\mathrm{mm}), K c=$ correction coefficient, taking into account the type of vegetation (dual crop coefficient) by ALLEN et al. [1998]:

$$
\begin{aligned}
K c_{(\text {ini-med })} & =\frac{K c_{\text {med }}-K c_{\text {ini }}}{n} \\
K c_{(\text {med-end })} & =\frac{K c_{\text {end }}-K c_{\text {med }}}{n}
\end{aligned}
$$

where: $n=$ number days in the considered period; $i n i$ $=15$ October; med $=21$ July; end $=25$ October

The $K c$ coefficient was calculated by adding the value obtained from the above equations to another $K c$ value of the day of the considered period, starting from the known $K c$ coefficients, e.g. $K c$ on $16.04=$ $K c_{i n i}$ (because it was the initial day, i.e. 15.04) + $K c_{\text {(ini-med) }} ; K c$ on $17.04=K c$ from the previous day, i.e. $K c$ of $16.04+K c_{(\text {ini-med) }}$.

Values of $K c$ were extracted from the publication of ALLEN [2000]. Some are shown in Table 2.

A value of $K c$ may also be described by the following equation [ALLEN 2000]:

$$
K c=K c b+K e
$$

where: $K c b=$ basal crop coefficient, describing transpirations, $K e=$ soil water evaporation coefficient, describing the soil evaporation.

Rainwater infiltrates to the interior of a soil profile. When the amount of water exceeds the retention capacity of soil, the excess may flow over the ground surface. The excess of water which cannot be absorbed by water-saturated soil is called surface runoff [RODRIGEZ-RODRIGEZ et al. 2012]. Moreover, the intensity of water saturation may be affected by the inclination of land [D'ARCY, CARIGNAN 1997] and by the soil profile or some geological features [DAMIANO et al. 2016]. Water retention in the individual catchments was recalculated relative to the surface area of a given catchment.

The water exchange in the tested lake is shown in Figure 3. The equation is as follows:

$$
I s-O s+P-E P \pm \Delta V=0
$$

where: $I s=$ surface inflows as the sum of inflows water by rivers, $O s=$ surface outflows by the river, $P=$ precipitation, $E P=$ evaporation (from the lake and rushes), $\Delta V=$ change in the retention.

In 2012, the water balance equation consisted of the sum of precipitation on the income side and evapotranspiration on the outgoing side. From 2013, measurements of the flow rate of surface water in the watercourse were carried out and therefore, in the years 2013-2014, the water balance equation con- sisted of the sum of precipitation and the surface inflow via the watercourses (on the income side) and the surface outflow via the watercourses (on the outgoing side).

Another measure of the water exchange rate, beside the water balance equation, is the ratio of the volume of water discharged from a lake to the lake's capacity - that is the duration of water exchange in a given water body or, to put it simply, water retention time in a water body. Apart from horizontal exchange, it is useful to calculate the vertical water exchange index (the ratio of the annual total evaporation from a lake to the lake's capacity) and the total exchange intensity index (the ratio of the outflow from a lake and evaporation from its surface to the lake's capacity).

The basic equation of BAC [1989] and PRZĄDKA [2009] served to estimate the evapotranspiration from the lake $(E P)$ while the previous equation [ALLEN 2000] was applied to estimate evapotranspiration from rushes. Unfortunately, data for the groundwater inflow and outflow during the analyzed period are unknown, hence these elements were excluded.

The evaporation from the lake's water surface was calculated from the formula proposed by BAC [1989] and PRZĄDKA [2009]:

$$
E P=0.36 d\left(1+0.5 u_{2}\right) n
$$

where: $d=$ average monthly moisture deficiency, $d=$ $E-e, E=$ maximum pressure of water vapour, $E=$ $6.1 \cdot 10^{(7.45 T) /(235+T)} ; e=$ current pressure of water vapour, $e=(R H \cdot E) / 100 ; R H=$ relative humidity of air, $R H=100(e / E) ; u_{2}=$ wind speed $(2 \mathrm{~m}$ above surface of area; $n=$ number of days per month.

Cropp coefficient for the Penman-Montheith formula. Among the considered plant types, rushes rooted in the lake's bottom $(K c>1)$, with the maximum evaporation in the high plant growing season, were characterized by the highest value of the evaporation correction coefficient, which depended on a species, age of plants or latitude. A high value of the coefficient was also calculated for grass $(K c=1.0-$ Tab. 2), forming dense plant cover and often having an anti-erosion effect.

Trees (particularly coniferous trees) are characterized by the lowest evaporation coefficient (Kc:

Table 2. Correction coefficients $K c$ (crop coefficient) for the Penman-Montheith formula, taking into account the indicative evaporation from the plants

\begin{tabular}{|l|c|c|c|}
\hline \multicolumn{1}{|c|}{ The type of land cover } & $K c_{\text {ini }}$ & $K c_{\text {med }}$ & $K c_{\text {end }}$ \\
\hline Coniferous forest & 0.7 & 0.65 & 0.65 \\
\hline Grass & 0.95 & 1.05 & 1.0 \\
\hline Pasture & 0.4 & 0.95 & 0.85 \\
\hline Wetlands (low vegetation) & 0.2 & 1.1 & 1.1 \\
\hline $\begin{array}{l}\text { Rushes/marsh vegetation - stagnant } \\
\text { water }\end{array}$ & 1.0 & 1.2 & 1.0 \\
\hline
\end{tabular}

Source: own elaboration based on LECHNIO [2005], ALLEN et al. [1998], ALLEN [2000]. 
0.65-0.67). When the average diurnal temperature exceeds $5^{\circ} \mathrm{C}$ (onset of a plant growing season), forest stands, particularly deciduous ones, evaporate most intensely. The water demand is high then because the leafage period starts.

The water velocity was measured using a Valeport current Meter. Then, the flow intensity was calculated based on the average water velocity in a crosssection and the cross-section's area of the stream.

\section{RESULTS}

In the hydrological years 2012-2014, the average sum of precipitation was $611.6 \mathrm{~mm}$ (Fig. 4), about 2\% higher than in the multi-year period: 1951-1975 [STACHY et al. 1987].

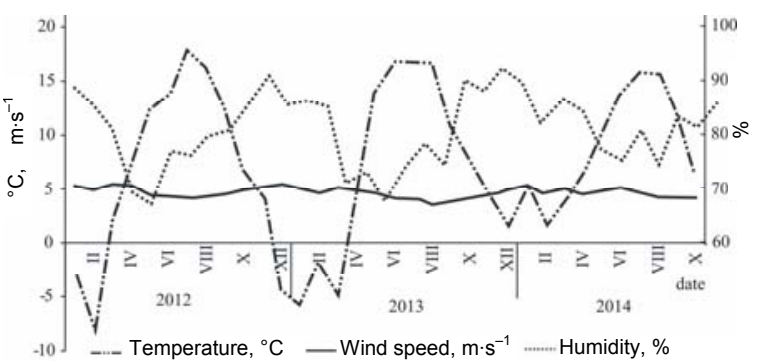

Fig. 4. Meteorological conditions in the vicinity of Lake Symsar (Lidzbark Warmiński station is located at a distance of approx. $8 \mathrm{~km}$ from the object); source: own study
The year 2012 can be regarded as a wet one, as the sum of precipitation was $827.5 \mathrm{~mm}$, which was $40 \%$ higher than the average precipitation in the multi-year period.

But due to high temperatures (approx. 21.16\% higher than in the compared period), it was also characterized by the highest water loss through evapotranspiration. The average temperature was $14.4^{\circ} \mathrm{C}$ in the plant growing season, and this was $6.7 \%$ higher than in the growing seasons from 1951 to 1975 . In the following years, the sums of precipitation were lower, for example in 2013 the sum of precipitation was approx. $572.3 \mathrm{~mm}$ (about $4.5 \%$ lower than in the multiyear period). The average temperature in that year was $7.32^{\circ} \mathrm{C}$. In turn, the year 2014 was dry, with the sum of precipitation being approx. $19.1 \%$ lower than in 1951-1975. The average wind velocity in the examined period (2012-2014) was $2.57 \mathrm{~m}^{3} \cdot \mathrm{s}^{-1}$, the strength of wind was the highest in the period from November through March.

In 2012-2014, the average water yield from the Symsarna River catchment area was $33.9 \mathrm{dm}^{3} \cdot \mathrm{km}^{-2} \cdot \mathrm{s}^{-1}$. The outflow was $48.14 \%$ higher in the growing season than in the remaining months, for example the water flow in the Tolknicka Struga during the plant growing period was almost twice as high as in the rest of the year (Tab. 3).

The situation was similar for SII (the flow was higher by approx. 2.5-fold). The lowest water yield

Table 3. The flow rate of surface waters in the catchment area of Lake Symsar and the magnitude of the water yield (as an amount of water outflows from the surface $1 \mathrm{~km}^{2}$ of their catchment areas in 1 second)

\begin{tabular}{|c|c|c|c|c|c|c|c|c|c|}
\hline \multirow{2}{*}{ Location } & \multirow{2}{*}{$\begin{array}{c}\text { Catchment area } \\
\mathrm{km}^{2}\end{array}$} & \multicolumn{9}{|c|}{ Flow rate, $\mathrm{dm}^{3} \cdot \mathrm{s}^{-1}$} & \multicolumn{3}{|c|}{ Water yield, $\mathrm{dm}^{3} \cdot \mathrm{s}^{-1} \cdot \mathrm{km}^{-2}$} \\
\cline { 3 - 11 } & 33.4 & 855 & 686 & 1227 & 214 & 25 & 24.54 & 29.63 & 23.10 \\
\hline SR-i & 19.2 & 100 & 27 & 178 & 55 & 55 & 6.13 & 7.06 & 3.12 \\
\hline TS & 2.7 & 47 & 18 & 61 & 19 & 40 & 13.96 & 13.23 & 16.24 \\
\hline SI & 1.4 & 22 & 10 & 30 & 9 & 39 & - & 28.20 & 9.88 \\
\hline SII & 22.9 & 1016 & 683 & 1460 & 340 & 33 & 56.59 & 46.79 & 33.02 \\
\hline SR-o & & &
\end{tabular}

Explanations: SR-i = Symsarna River inflow (part of catchment from Blanki Lake to the outflow from Symsar Lake); TS = drainage ditch Tolknicka Struga; SI = stream I (forestry-agricultural catchment; SII = stream II (agro-forestry catchment); SR-o = Symsarna River - outflow (part of cachment from Symsar Lake, to the inflow called the Kierwińska Struga).

Source: own study.

was characteristic for the SI catchment area, where periodical water decrements during a drought period occurred in the stream. In 2012-2014, the average flow from the catchment surface area amounted to $33.0 \mathrm{dm}^{3} \cdot \mathrm{km}^{-2} \cdot \mathrm{s}^{-1}$. In the plant growing season, the outflow from the catchment area was higher by $36 \%$ than during the other months. The availability of water in the riverbeds in the subsequent years of research declined, which was attributed to the decreasing amounts of rainfall.

An important role in water retention was played by the forests in the catchment area, e.g. for stream I, where forests occupy $57.9 \%$ of the catchment's surface area, more than $6000 \mathrm{~m}^{3}$ of water per hectare was retained. Somewhat less water evaporated from the terrain with natural mosaic cover [ŚLĄZEK 2014].
Unfavourable to the storage of water are barren areas and arable land. In the structure of land use within the Tolknicka Struga's catchment area, arable land prevailed. Such land cover is characterized by quite high evaporation from its surface and therefore the transpiration from plant surfaces constituted $98.2 \%$ of total evapotranspiration.

In the analyzed period (2012-2014), the sum of evaporation and transpiration from the direct catchment area via plants, i.e. forests and pastures, amounted to $1245 \mathrm{~m}^{3} \cdot \mathrm{ha}^{-1}$. On the other hand, the sum of precipitation was at a level of $3974 \mathrm{~m}^{3} \cdot \mathrm{ha}^{-1}$. The amount of water reaching the surface with atmospheric precipitation was over $35 \%$ higher than the amount evaporating from it (Fig. 5). 


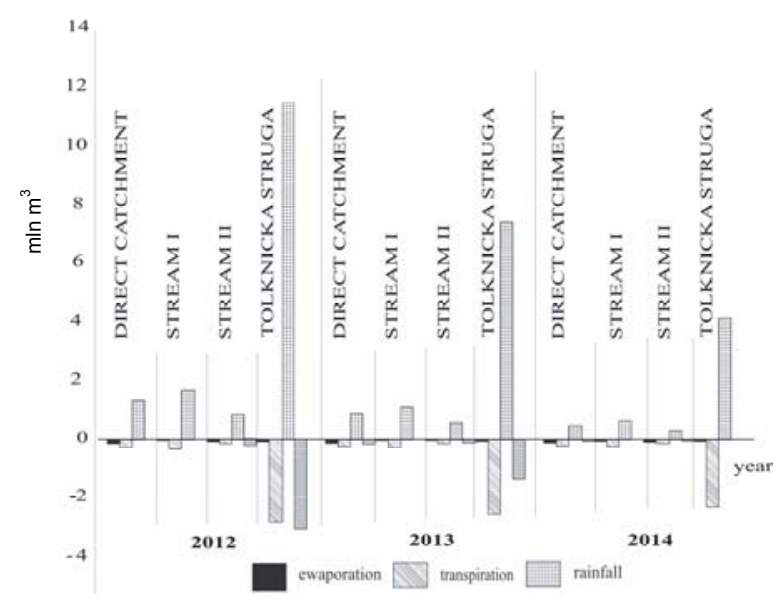

Fig. 5. Water retention in the partial catchments of Lake Symsar; source: own study
The most intensive evaporation appeared in the grassland, which constituted $49.5 \%$ of the whole catchment's area surface. In the years 2012-2014, availability of water was observed in the catchment area of stream I. In the structure of this catchment area, wooded areas prevailed (coniferous forests), which generally have a favourable impact on water retention.

Symsar Lake and the Symsarna River represent a river-lake system, typical of a postglacial landscape. The main sources of water supply are surface inflows, while less water is delivered through precipitation (Fig. 6).

For example, precipitation and surface inflow introduced approx. $296000 \mathrm{~m}^{3} \cdot \mathrm{ha}^{-1}$ of water in 2013.

The contribution of the surface inflows to the total water income was as much as $89.4 \%$. The amount

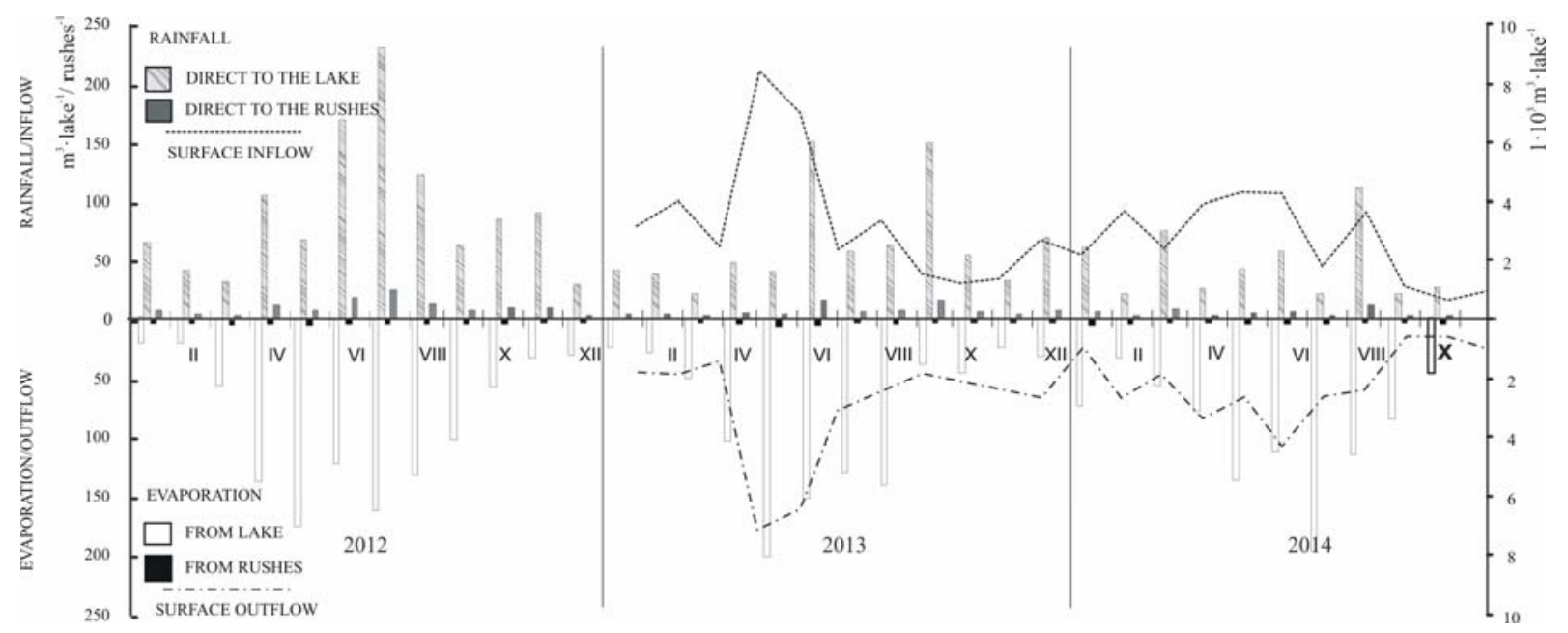

Fig. 6. Vertical water exchange in Lake Symsar; source: own study

of water drained from the lake reached 273000 $\mathrm{m}^{3} \cdot \mathrm{ha}^{-1}$, with $3.7 \%$ lost by evaporation (including from the rush surface), and $90.0 \%$ by the outflow. Because 2014 was a dry year, the water income to Lake Symsar was lower than in the previous year, approx. $205.000 \mathrm{~m}^{3} \cdot \mathrm{ha}^{-1}$ of the lake's surface, with $82.7 \%$ lost by the surface inflow. Approximately $3.8 \%$ of the outgoing water left through evaporation.

The Symsarna River divides Lake Symsar into two parts: the main one, through which the river flows, and a bay. The volume of water in the northern bay does not exceed $4 \%$ of the whole lake's water holding capacity. The maximum depth of the bay is $5 \mathrm{~m}$. The bay is fed with waters from a small stream denoted as SL, which does not have a surface outflow. The bay therefore presents characteristics of a closed water body and no horizontal water exchange takes place in it. However, the vertical type of water exchange plays a significant role in the water circulation within the bay. It occurs through evaporation from the surface of rushes and from the surface of open lake waters. The bay, similarly to the rest of the lake, lies in a land depression, and its shores are predominatly covered with forest. Based on the calculated evapora- tion indices, whose values depended on the meteorological conditions in 2012-2014, it can be concluded that waters in the bay are mixed at least once a year, every 238 days and 6 hours. Evaporation from the surface of rush plants (covering around $12 \%$ of the bay's surface) is responsible for around 4\% of total water loss. The remaining water is evaporated from the open water surface of the bay. The intensity of water evaporation depended on the sum of precipitation and on high temperatures.

\section{DISSCUSION}

Water bodies like Lake Symsar, as elements of river-lakes systems, are susceptible to frequent exchanges of water. In Lake Symsar, the percentage of water exchange, seen as the intensity of water outflow from the lake, was 23\% a year [SIDORUK, POTASZNIK 2011]. The water exchange percentage in a water body during a year determines the cycling of matter in that water body and influences the quality of its water. Water exchange involves different parts of water masses in a lake, depending on a current thermal structure. Frequently, water exchange is implicated in 
water bodies undergoing circulation because a water current prevents accumulation of substances, which is likely to happen in lakes like Lake Symsar. Short water retention time favours the accumulation of nutrients in the hypolimnion, where water is colder and denser, and therefore water exchange does not proceed as intensively as in the more superficial water layers in the epilimnion [BORSUK 2014]. The total exchange of water in Lake Symsar (including vertical and horizontal exchange) takes approx. 66 days and 14 hours. Water bodies like Lake Symsar, as elements of river-lakes systems, are vulnerable to frequent exchanges of water [HILLBRICHT-ILKOWSKA, WIŚNIEWSKI (eds) 1996]. Lakes with small surface areas are more susceptible to variable hydrological conditions: prolonged changes in the precipitation regime, groundwater escape. The catchment area's surface and its land use are basic factors affecting the water balance of the catchment area [CARDILLE 2004]. The horizontal exchange coefficient for the tested lake (or the ratio of the amount of water flowing out from the lake to its total volume) was 4.98 , meaning that the lake's water was exchanged by horizontal exchange (inflow-outflow) every 73 days and 7 hours. The intensity of water exchange favours the resistance of an aquatic ecosystem to eutrophication, because it limits excessive accumulation of biogenes in the water body [WIŚNIEWSKI et al. 2007]. In our case study of Lake Symsar, the Symsarna River was responsible for the introduction of approximately $72.0 \%$ of general water originating from the surface inflows. The rest of the water was introduced by the Tolknicka Struga (TS), stream I (SI) and stream II (SII). Lake Symsar was characterized by a relatively low coefficient of vertical exchange of water: 0.41 (calculated as the ratio of evaporated water amount to total volume). The contribution of this exchange amounted to only $11.4 \%$ of the total water exchange. In a study by WIŚNIEWSKI et al. [2007], the contribution of vertical exchange in Dabie Lake, located in the delta of the Odra River, did not even reach $1 \%$. Evapotranspiration could be an important component of a water cycle equation in river catchment areas. In the balance of Polish rivers, it constitutes about 70\% of water loss [ŚLĄZEK 2014]. Evapotranspiration depends on variable meteorological conditions, the soil type, slope and land use (in Poland, mosaic development of landscapes dominantes). Evapotranspiration can be estimated for large catchment areas, even where hydrogeological parameters of the soil are unavailable [ŚLAZZEK 2014]. Precipitation is a decisive factor influencing the magnitude of evaporation from forest catchment areas [WANG et al. 2011]. The largest amount of water is evaporated in July, which correlated with the intensity of precipitation. The lowest land evaporation from a catchment area dominated by drained agricultural areas was observed in the non-vegetation season [MICHALCZYK et al. 2002]. The higher values of evaporation were characteristic for open lake surfaces. The evaporation from reed fields equals $10 \mathrm{~mm} \cdot \mathrm{d}^{-1}$ and only sometimes reaches $20 \mathrm{~mm} \cdot \mathrm{d}^{-1}$, thus being higher than in wooded areas [HERBST, KAPPEN 1999]. Rushes play an important role in shaping microclimate and hydrological conditions, because they reduce humidity deficiencies in the air and increase the amount of precipitation [HERBST, KAPPEN 1999].

In Lake Symsar, which represents an element of a river and lake system, evaporation from the surface of rushes was small because the percentage cover composed of these plants was small as well, approximating $11 \%$. Nevertheless, evaporation from the surface of the water body did not affect significantly the lake's water balance. The location of the lake in a post-glacial channel, large differences in the elevation of the area and the forest cover of the immediate catchment around the lake limited the vertical water loss. The availability of water in the analyzed river and lake system was mostly influenced by the surface inflow and outflow, i.e. the vertical type of water exchange.

\section{CONCLUSIONS}

Based on the studies carried out on the variability of hydrological conditions of the catchment of a lake representing a river-lake system as a response to changing meteorological conditions of water availability in catchments, it can be concluded that despite quite high total exchange of the water (inflowoutflow) in Lake Symsar (every 66 days and 14 hours), the analyzed river-lake system was characterised by water retention abilities. The sum of evapotranspiration and the sum of precipitation in the riverlake system had a minimal influence on the formation of water resources. Mainly, the water of the Symsarna River affected the balance between the water income and the water outgoings in the lake.

The land use of the catchment area seems to play a very important role in the local water cycle, because the studies proved that the water retention was favoured by wooded and marshy areas. The highest retention capacity was characteristic for the inflow's catchment areas where wooded areas, arable land and marshes prevailed. On the other hand, wasteland and large height differences of the terrain are unfavourable to water retention, intensifying soil evaporation and accelerating the water run-off outside of the catchment area. Among possible measures to limit water deficits in an agricultural-forest catchment area of a river-lake system, the rational use and management of the catchment land are recommended. Broadscale actions aimed at the amelioration of poor local retention capacity may contribute to some improvement in water resources regionally and even globally. 


\section{REFERENCES}

ALLEN R.G. 2000. Using the FAO-56 dual crop coefficient method over an irrigated region as part of an evapotranspiration intercomparison study. Journal of Hydrology. Vol. 229. Iss. 1-2 p. 27-41.

Allen R.G., Pereira L.S., Raes D., Smith M. 1998. Crop evapotranspiration - Guidelines for computing crop water requirements. FAO Irrigation and Drainage Paper 56. Rome. FAO. ISBN 92-5-104219-5 pp. 328.

BAC S. 1989. Współzależność miesięcznych i dekadowych wielkości ewapotranspiracji według Penmana z parowaniem $\mathrm{z}$ wolnej powierzchni wody $\mathrm{w}$ świetle dwudziestoletnich badań [Interrelationships of monthly and decade values of evapotranspiration acc. to Penman with evaporation from free water surface based on twenty years' research]. Zeszyty Naukowe AR we Wrocławiu. Ser. Melioracje. Z. 191 p. 99-109.

BAJKIEWICZ-GrabOWSKa E., MikUlSKi Z. 1996. Hydrologia ogólna [General hydrology]. Warszawa. ISBN 978-8301-14579-8 pp. 297.

BORSUK S. 2014. Ekologiczno-geochemiczny system oceny jakości wód jeziornych. Problemy. Metodologia. Modelowanie [Ecological-geochemical assessment system of lake water quality]. Bydgoszcz. Wydaw. Uczelniane UTP pp. 198.

CARdille J., CoE M.T., VAno J.A. 2004. Impacts of climate variation and catchment area on water balance and lake hydrologic type in groundwater-dominated systems: a generic lake model. Earth Interaction. Vol. 8. Iss. 13 p. 1-22.

Chodak T., Kaszubriewicz J., Tasz W. 2005. Skład granulometryczny i zawartość makroskładników w materiale glebowym zmywanym w wyniku erozji powierzchniowej [Grain size distribution and macronutrients content in soils washed away during surface erosion]. Acta Agrophysica. Vol. 5. Iss. 3 p. 577-587.

Damiano E., Greco R., Guida A., Olivares L., Picerelli L. 2016. An investigation of infiltration and deformation processes in layered small-scale slopes in pyroclastic soils. In: Volcanic rocks and soils. Eds T. Rotonda, M. Cecconi, F. Silvestri, P. Tommasi. London. Taylor and Francis Group p. 163-166.

D'ARCY P., CARIGNAN R. 1997. Influence of catchment topography on water chemistry in southeastern Québec Shield lakes. Canadian Journal of Fisheries and Aquatic Sciences. Vol. 54. Iss. 10 p. 2215-2227.

Dupont S., Pivato D., Brunet Y. 2015. Wind damage propagation in forests. Agricultural and Forest Meteorology. Vol. 214. DOI: 10.1016./j.agrformet.2015.07.010 p. 243-251.

FARMANi R., Butler D., Hunt D.V., Memon F.A., AbDElMEguid H., WARD S., Rogers C.D. 2012. Scenariobased sustainable water management and urban regeneration. Proceedings of the ICE-Engineering Sustainability. Vol. 165. Iss. 1 p. 89-98.

Geoportal undated. Kataster [online]. [Access: 08.12.2016]. Available at: http://mapy.geoportal. gov.pl/imap/ ?gpmap $=$ gp0\&actions $=$ acShowServices_KATASTER

Haddeland I., Heinke J., Biemans M., Eisner S., Flörke M., HANASAKI N., KonZMANN M., Ludwig L., MASAKI Y., Schewe J., Stacke T., Tessler Z.D., WadA Y., WisSER D. 2014. Global water resources affected by human interventions and climate change. Proceedings of the National Academy of Sciences. DOI: 10.1073/ pnas.1222475110. p. 3251-3256.
HeRBST M., KAPPEN L. 1999. The ratio of transpiration versus evaporation in a reed belt as influenced by weather conditions. Aquatic Botany. Vol. 63 p. 113-125.

HILLBRICHT-ILKOWSKA A., WIŚNIEWSKI R.J. (eds) 1996. Funkcjonowanie systemów rzeczno-jeziornych w krajobrazie pojeziernym: rzeka Krutynia (Pojezierze Mazurskie) [The functioning of river-lake system in a lakeland landscape: river Krutynia (Mazurian Lakeland, Poland)]. Zeszyty Naukowe PAN „Człowiek i Środowisko”. Z. 13. Dziekanów Leśny. Ofic. Wydaw. Instytutu Ekologii PAN. ISBN 8387089028 pp. 342.

KondRACKI J. 2000. Geografia regionalna Polski [Regional geography of Poland]. Warszawa. Wydaw. Nauk. PWN ISBN 83-01-12479-2 pp. 440.

LECHNIO J. 2005. Hydrologiczne warunki obiegu substancji w obrębie wariantów krajobrazu. W: Z problematyki funkcjonowania krajobrazów nizinnych [Hydrological conditions of the circulation of substances within the landscape variants. In: On the issue of the functioning of lowland landscapes]. Eds A. Richling, J. Lechnio. Warszawa. UW p. 95-126.

MichalCZYK Z., BARTOSZEWSKI S., TURCZYŃSKi M. 2002. Water conditions of Polesie region. Acta Agrophysica. Vol. 66 p. 49-76.

OKońSki B., Miler A.T., PANFil M. 2009. The dynamic of climate elements and land drainage impact on hydrological conditions in lakeland blind drainage area. Journal of Water and Land Development. No. 13a p. 225238. DOI: $10.2478 / 110025.010 .0030 .9$.

PotAszNiK A., SZymCZyK S., SidoruK M., ŚwitAJSKA I. 2014. Role of Lake Symsar in the reduction of phosphorus concentration in surface runoff from agricultural lands. Journal of Water and land Development. No. 20 p. 39-44. DOI: 10.2478/jwld-2014-0006.

PRZĄDKA Z. 2009. Porównanie wyników oceny parowania jeziora Łękuk uzyskanych metodą obliczeniową i pomiarową [Comparison of evaporation estimation results for Łękuk Lake obtained by calculation and measurement methods]. Monitoring Środowiska Przyrodniczego. Nr 10 p. $73-78$.

RodríGUEZ-RodríGUez M., GreEn A.J., LÓPEZ R., MARTOS-RosiLlo S. 2012. Changes in water level, land use, and hydrological budget in a semi-permanent playa lake, Southwest Spain. Environmental Monitoring Assessment. Vol. 184. Iss. 2 p. 797-810. DOI: 10.1007/ s10661-011-2002-1.

Schewe J., Heinke J., Gerten D., Haddeland I., Arnell N.W., CLARK D.B. et al. 2014. Multimodel assessment of water scarcity under climate change. Proceedings of the National Academy of Sciences. Vol. 111. No. 9 p. 3245-3250. DOI: 10.1073/pnas.1222460110.

SidoruK M., PotaszNIK A. 2011. Stan trofii jeziora Symsar i możliwości jego poprawy [The trophic status of Symsar Lake and possibilities of its improvement]. Inżynieria Ekologiczna. Z. 26 p. 221-229.

SiŁUCH M., BARTOSzeK K. 2012. Możliwości wykorzystania danych satelitarnych do wyznaczania początku i końca okresu wegetacyjnego [The use of satellite data for determining the onset and the end of a plant growing season]. Woda-Środowisko-Obszary Wiejskie. T. 12. Z. 2 (38) p. 245-255.

Soja G., ZÜGer J., Knoflacher M., Kinner P., Soja A.M. 2013. Climate impacts on water balance of a shallow steppe lake in Eastern Austria (Lake Neusiedl). Journal of Hydrology. Vol. 480 p. 115-124. DOI: 10.1016/ j.jhydrol.2012.12.013. 
Stachy J., Bieluk J., CZarnecka H., Baranowski L. 1987. Atlas hydrologiczny Polski [Hydrological atlas of Poland]. Warszawa. IMGW, Wydaw. Geol.

Sun R., CHEN L. 2012. How can urban water bodies be designed for climate adaptation? Landscape and Urban Planning. Vol. 105. Iss. 1-2 p. 27-33. DOI: 10.1016/ j.landurbplan.2011.11.018.

ŚLAZZEK M. 2014. Analysis of evapotranspiration in the catchment of the Nurzec River, Poland using MODIS data. Miscellanea Geographica - Regional Studies On Development. Vol. 18. Iss. 1 p. 44-51. DOI: 10.2478/ mgrsd-2014-0008.

WACNIK A., KupryJanOWiCZ M., Mueller-BIEnieK A., KARCZEWSKI M., CYWA K. 2014. The environmental and cultural contexts of the late Iron Age and medieval settlement in the Mazurian Lake District, NE Poland: combined palaeobotanical and archaeological data. Vegetation History And Archaeobotany. Vol. 23. Iss. 4 p. 439-459. DOI 10.1007/s00334-014-0458-y.
Wang S., Fu B.J., He C.S., Sun G., GaO G.Y. 2011. A comparative analysis of forest cover and catchment water yield relationships in northern China. Forest Ecology and Management. Vol. 262. Iss. 7 p. 1189-1198. DOI: 10.1016/j.foreco.2011.06.013.

WassenaAr L.I., Athanasopoulos P., Hendry M.J. 2011. Isotope hydrology of precipitation, surface and ground waters in the Okanagan Valley, British Columbia, Canada. Journal of Hydrology. Vol. 411. Iss. 1-2 p. 37-48. DOI: 10.1016/j.jhydrol.2011.09.032.

WIOŚ Olsztyn, IOŚ 2012. Raport o stanie środowiska województwa warmińsko-mazurskiego w 2011 roku [Report on the state of the environment of Warmia and Mazury in 2011]. Biblioteka Monitoringu Środowiska Olsztyn pp. 121.

WiŚNIEWSKi M., Wolski T., BuchHOLZ W., KREFT A. 2007. Bilans wód jeziora Dąbie [The water balance of Lake Dąbie]. Infrastructure and Ecology of Rural Areas. Z. 4/2 p. 211-221.

\section{Angela B. KURIATA-POTASZNIK, Sławomir SZYMCZYK \\ Zmienność dostępności wody w systemie rzeczno-jeziornym - jezioro Symsar}

\section{STRESZCZENIE}

Przewiduje się, że zmiany klimatyczne doprowadzą do zmniejszenia zasobów wodnych zarówno w skali globalnej, jak i regionalnej. Lokalne zmiany klimatu są trudniejsze do zaobserwowania i dlatego, aby przeciwdziałać ich skutkom, wskazane wydaje się podjęcie wszelkich badań nad warunkami regionalnymi oraz lokalnymi. Celem prezentowanych badań była ocena wpływu rzeki oraz jej zlewni na zmienność dostępności wody w naturalnym jeziorze należącym do polodowcowego systemu rzeczno-jeziornego. Systemy rzeczno-jeziorne zachowują się najczęściej jak jedna, interakcyjna jednostka hydrologiczna, a intensywność wymiany wody w tych systemach jest dość duża, co może powodować chwilowe ubytki wody. W wyniku badań stwierdzono, że woda w analizowanym systemie była wymieniana co ok. 66 dni, co wynikało z całkowitej (poziomej i pionowej) wymiany wody. Również zarządzanie zlewnią wydaje się odgrywać kluczową rolę w lokalnej dostępności wody; w niniejszych badaniach obszary leśne i bagienne sprzyjały zatrzymywaniu wody. W zlewni, w której dominowały lasy, pastwiska i tereny podmokłe, obserwowana była intensywniejsza retencja wody. Występowanie nieużytków i dużych deniwelacji terenu w badanej zlewni nie sprzyjało retencji wody, ponieważ intensyfikowało parowanie gleby i przyspieszało odpływ wody poza zlewnię. Wśród działań, które powinny zostać podjęte w celu przeciwdziałania stratom wody w zlewniach, najczęściej wymienia się racjonalne wykorzystanie i zarządzanie zasobami gruntów w zlewni.

Słowa kluczowe: opad atmosferyczny, parowanie terenowe, system rzeczno-jeziorny, warunki hydrologiczne, warunki meteorologiczne 